
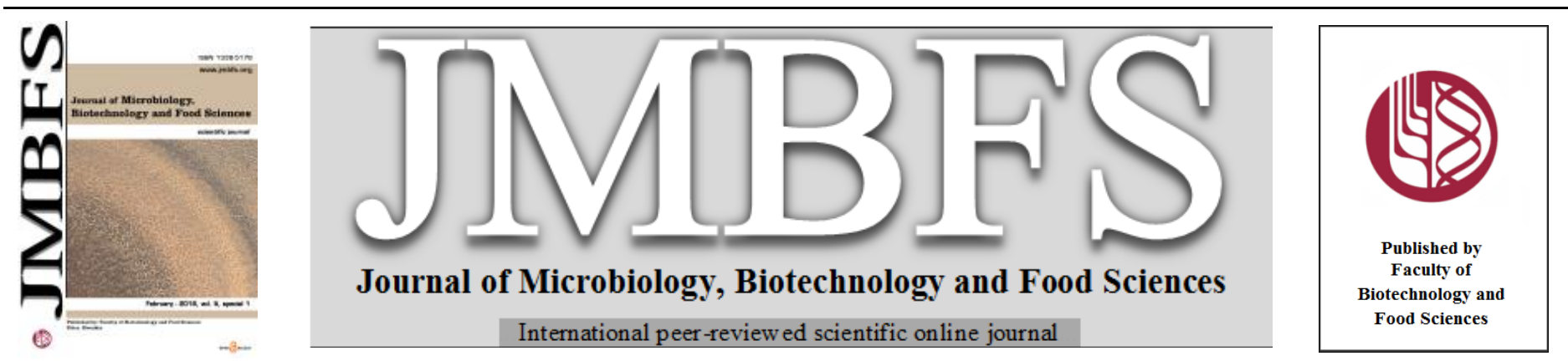

\title{
MICROBIOLOGICAL QUALITY OF READY-TO-EAT FOODS PRODUCED IN SLOVAKIA
}

\author{
Lubomir Lopašovský, Margarita Terentjeva ${ }^{2}$, Simona Kunová ${ }^{1}$, Lucia Zeleňáková ${ }^{1}$, Miroslava Kačániová ${ }^{3}$
}

Address(es): MVDr. L'ubomír Lopašovský, PhD.,

${ }^{1}$ Slovak University of Agriculture, Faculty of Biotechnology and Food Sciences, Department of Food Hygiene and Safety, Tr. A. Hlinku 2, 94976 Nitra, Slovak Republic.

${ }^{2}$ Institute of Food and Environmental Hygiene, Faculty of Veterinary Medicine, Latvia University of Agriculture, K. Helmana iela 8, LV-3004, Jelgava, Latvia.

${ }^{3}$ Slovak University of Agriculture, Faculty of Biotechnology and Food Sciences, Department of Microbiology, Tr. A. Hlinku 2, 94976 Nitra, Slovak Republic.

*Corresponding author: lubomir.lopasovsky@uniag.sk

doi: 10.15414/jmbfs.2016.5.special1.31-35

\section{ARTICLE INFO}

Received 17. 12. 2015

Revised 13. 1. 2016

Accepted 22. 1. 2016

Published 8. 2. 2016

Regular article OPEN $\partial_{\text {ACCESS }}$

\begin{abstract}
The purpose of this study was to evaluate the microbiological quality of Ready-To-Eat (RTE) foods produced in Slovakia. A total amount of 144 samples of RTE food were tested during one-year period from January to December, 2014 and the microbiological quality of kebabs $(n=30)$, gyros $(n=10)$, hamburgers $(n=54)$, cheeseburgers $(n=5)$, hot-dogs $(n=31)$, roasts $(n=14)$ was analyzed. The samples were examined for the presence of: coliform bacteria, sulfite-reducing clostridia, yeast, microscopic filamentous fungi and coagulase positive staphylococci according to the ISO standards requirements. In kebab samples the counts of coliforms were from $<10$ to $1.6 \times 10^{3} \mathrm{cfu}_{\mathrm{g}} \mathrm{g}^{-1}$ and incompliance was found in $12 / 30(40 \%)$ of samples. Maximum counts of coliforms and yeasts were exceeded in two and one sample of gyros and isolation range was from 10 to $1.5 \times 10^{3} \mathrm{cfu} . \mathrm{g}^{-1} 3.2 \times 10^{2} \mathrm{cfu} . \mathrm{g}^{-1}$ and from 10 to $1.4 \times 10^{2} \mathrm{cfu} . \mathrm{g}^{-1}$. Also $2 / 5$ (40\%) of samples of cheeseburger yielded unsatisfactory coliform counts and the isolation rates were from less than 10 to $1.5 \times 10^{3} \mathrm{cfu} . \mathrm{g}$ ${ }^{1}$. In hot-dogs, counts of coliforms, yeasts and coagulase positive staphylococci ranged from less than 10 to $1.4 \times 10^{3}$, $<10$ to $2.1 \times 10^{3}$ cfu.g ${ }^{-1}$ and $<10$ to $1.4 \times 10^{2}$ cfu.g $^{-1}$ and number of unsatisfactory samples were $3 / 31(10), 1 / 31(3)$ and $1 / 31$ (3), respectively. In roast, the counts of coliforms, yeasts and microscopic filamentous fungi were from less than 10 to $2.1 \times 10^{2} \mathrm{cfu}_{\mathrm{g}} \mathrm{g}^{-1}$, less than 10 to $1.4 \times 10^{2} \mathrm{cfu}^{\mathrm{g}} \mathrm{g}^{-1}$ and less than 10 to $3.2 \times 10^{2} \mathrm{cfu}^{-1} \mathrm{~g}^{1}$, respectively and the safety criteria were not met for 1/14 (7) samples for each of the bacteria group mentioned. Overall, the microbiological criteria set for RTE foods in Slovak Republic were violated in 36/ 144 (25) of samples tested. Results of the present study show that RTE foods might pose public health concerns in Slovakia and more attention on the hygienic practices should no paid.
\end{abstract}

\section{INTRODUCTION}

Controlling and improving of the quality and safety of chilled foods at all stages of the cold chain have always been among the main concerns in order to reduce food losses and eliminate public health hazards. Changes in microbial and physico-chemical quality of foods may occur during their shelf-life that is linked to storage temperature, as well as to the composition and properties of a product. Meat and processed meat products are ideal media for the growth of spoilage and pathogenic bacteria therefore the quality and safety of meat could change significantly during the shelf-life. Pork meat and Ready-To-Eat (RTE) pork meals are the main type of meat consumed in Europe (Mataragas et al., 2008; Verbeke et al., 2010).

RTE food is defined as food that can be consumed immediately at the point of sale without further preparation or treatment. It could be raw, partially or fully cooked, and hot, chilled or frozen (FEHD, 2007; USFDA, 2009). RTE food can be of animal and plant origin including fruits, vegetables and bakery products (USFDA, 2009). Since RTE foods are consumed without additional treatment, a risk of foodborne disease outbreaks linked to the consumption of RTE food are high if is the food was improperly handled. RTE foods were a source of bacterial foodborne outbreaks and various foodborne pathogens have been found in the RTE products in previous studies (Castro-Rosas et al., 2012; Seow et al., 2012). Methods of storage, processing, handling and distribution of RTE products can affect the numbers of microorganisms (Christison et al., 2008; Fang et al., 2003).

The catering business provides food and beverages to people and covers all sectors of society such as childcare, schools, hospitals, nursing homes, restaurants, bars, take-away and fast-food outlets (Garayoa et al., 2011). This industry has expanded greatly and undergone profound changes in recent years. Many factors have contributed to this including changes in lifestyle, and business, travelling as well as increased purchasing power (Garayoa et al.,
2011). With globalization, the foodborne diseases (FBDs) have acquired a new dimension, as many food products are produced in one country to be imported and consumed in another (Martins and Germano, 2008). The increased international travel, as more affordable, has determined a FBDs globalization (Käferstein et al., 1997). Many infectious diseases, including a variety of gastrointestinal disorders, are contracted by individuals while travelling outside their country of residence (Evans 2006; Ravel et al., 2011). The World Tourism Organization (WTO), a specialized agency of the United Nations (UN), estimates world tourist arrivals at 940 million in 2010 (UNWTO, 2011). The World Health Organization (WHO) reports that up to $30 \%$ of individuals in developed countries suffer from food and water related diseases annually (WHO, 2007). The European Union (EU) Summary Report on foodborne outbreaks in 2009 indicated a total of 5550 foodborne outbreaks, with 48,964 human cases, 4356 hospitalizations and 46 deaths. The EU's annual report also showed that up to 63.6\% of FBDs were associated with foodservice catering (EFSA, 2011).

In recent years, several studies (Almualla et al., 2010; Chapman et al., 2010; Garayoa et al., 2011; Gillespie et al., 2000; Legnani et al., 2004; Marzano and Balzaretti, 2011; Martinez-Tomè et al., 2000; Rodríguez et al., $2011 \mathrm{a}$, b; Santana et al., 2009; Tessi et al., 2002; Veiros et al., 2009; Yoon et al., 2008) have been conducted aiming to evaluate the microbiological quality and safety of RTE foods prepared and served by catering business in many sectors of society schools, hospitals, supermarkets, hotels, long term care facilities, canteens for workers, mass catering establishments, however, knowledge about the microbiological contamination of RTE foods in Slovakia is very limited, therefore the aim of the study was to evaluate the microbiological quality of selected ready-to-eat products. In our study we analyzed the microbiological quality of kebabs, gyros, hamburgers, cheeseburgers, hot - dogs and roasts by detection of coliform bacteria, sulfite-reducing clostridia, yeast, microscopic filamentous fungi and coagulase positive staphylococci. 


\section{MATERIAL AND METHODS}

\section{Sampling}

Samples were obtained from the nearby fast food establishments in the Nitra region -shops, supermarkets and catering enterprises. After sampling, samples were delivered to the Regional Institute of Public Health of Regional Public Health Authority in Nitra accredited laboratory for microbiological testing. A total amount of 144 samples of RTE food for the period of one year from January to December 2014 was investigated. The samples were kebabs $(n=30)$, gyros $(n=10)$, hamburgers $(n=54)$, cheeseburgers $(n=5)$, hot-dogs $(n=31)$, roasts $(n=14)$ were used in this study. The samples were examined for the presence of the following groups of microorganisms: coliform bacteria, sulfite-reducing clostridia, yeast, microscopic filamentous fungi and coagulase positive staphylococci.

\section{Microbiological analysis}

An amount of $5 \mathrm{~g}$ of ready-to-eat food was homogenized with $45 \mathrm{~mL}$ of sterile peptone saline solution for $1 \mathrm{~min}$ in order to obtain the initial dilution. For quantitative detection of microorganisms the ten-fold dilution from $10^{-2}$ to $10^{-4}$ were made. After preparation of sample, for detection of the total coliforms the suspension was plated out on Violet Red Bile agar (Merck, Darmstadt, Germany) and incubated at $37^{\circ} \mathrm{C}$ for $24 \mathrm{~h}$ (STN EN ISO 4832). Detection of coagulase positive staphylococci was done on Baird-Parker egg yolk tellurite agar incubated at $37^{\circ} \mathrm{C}$ for $24 \mathrm{~h}$ according to STN ISO EN 6888-1. For testing of Clostridium perfringens (STN ISO EN 13401), suspension was plated onto Tryptose Sulphite Cycloserine agar incubated at $37{ }^{\circ} \mathrm{C}$ for $24-48$ hour in anaerobically condition. Detection of yeast and microscopic filamentous fungi was undertaken on Dichloran Rose Bengal Chlortetracycline or Dichloran glycerol agar at $25^{\circ} \mathrm{C}$ for 5 days (STN ISO EN 21527 - 2). After incubation the bacterial colonies with typical morphology resembling the target microorganisms were selected from each Petri dish and all typical colonies were enumerated. Evaluating of the results have been doing by applicable Codex Alimentary of the Slovak Republic reflected in Table 1 (CA SR, 2006).

Table 1 Criteria of production process hygiene for ready-to-eat food

\begin{tabular}{lcccc}
\hline Microorganisms & $\mathbf{n}$ & $\mathbf{c}$ & $\mathbf{m}$ & $\mathbf{M}$ \\
\hline $\begin{array}{l}\text { Coliform bacteria } \\
\begin{array}{l}\text { Sulfite-reducing } \\
\text { clostridia }\end{array}\end{array}$ & 5 & 2 & $10^{2}$ & $5 \times 10^{2}$ \\
$\begin{array}{l}\text { Yeasts } \\
\begin{array}{l}\text { Microscopic } \\
\text { filamentous fungi }\end{array}\end{array}$ & 5 & 2 & 50 & $10^{2}$ \\
$\begin{array}{l}\text { Coagulase positive } \\
\text { staphylococci }\end{array}$ & 5 & 2 & $10^{3}$ & $2 \times 10^{4}$ \\
\hline
\end{tabular}

$\mathrm{m}=$ minumum number of microorganisms in the sample size $, \mathrm{n}^{\prime \prime}, \mathrm{M}=$ maximum number of microorganisms in the specified amount of sample, which allows the maximum number of samples „c"., $\mathrm{c}=$ the number of samples from „n“" with values between " $\mathrm{m}$ " and " $\mathrm{M}$ " of the bacterial counts in other samples do not exceed " $\mathrm{m}$ "

\section{RESULTS AND DISCUSSION}

Homemade foods are taken as RTE for sale on the street or for the consumption, therefore, are one of the most susceptible to microbial growth in view of the longer length of time between preparation and consumption under improper temperature conditions, besides the unusual step of reheating the foods before consumption. In the case of streetmade foods, the raw materials are usually industrially processed and either prepared in advance or on demand. Environmental conditions faced by the street vendors are an important risk factor to the safety of the food sold. Nevertheless, no difference was found between the microbial counts of home- and street-made samples in Hanashiro et al. (2005) study. It is presumable that the sanitary and structure conditions are not better at the handlers' home and neighborhood added to the fact that food handling practices are the same no matter the place (Hanashiro et al., 2005).

$\underline{\text { Table } 2 \text { Microbiological quality of kebab samples }(\mathrm{n}=30)}$

\begin{tabular}{lcc}
\hline Microorganisms & Results & $\begin{array}{c}\text { No. of unsatisfactory } \\
\text { samples } / \text { No. of samples } \\
(\%)\end{array}$ \\
\hline $\begin{array}{l}\text { Coliform bacteria } \\
\text { Sulfite-reducing } \\
\text { clostridia }\end{array}$ & $<10-1.6 \times 10^{3} \mathrm{cfu}^{-1}$ & $12 / 30(40)$ \\
$\begin{array}{l}\text { Yeasts } \\
\text { Microscopic }\end{array}$ & $<10 \mathrm{cfu} . \mathrm{g}^{-1}$ & $0 / 0(0)$ \\
filamentous fungi & $<10-5.0 \times 10^{2} \mathrm{cfu} . \mathrm{g}^{-1}$ & $0 / 0(0)$ \\
$\begin{array}{l}\text { Coagulase } \\
\text { positive } \\
\text { staphylococci }\end{array}$ & $<10 \mathrm{cfu} . \mathrm{g}^{-1}$ & $0 / 0(0)$ \\
\hline
\end{tabular}

In kebabs, the number of coliform bacteria were in the range from $<10$ to $1.6 \times 10^{3}$ cfu. $^{-1}$ (Table 2) and 12 (40\%) samples of kebab did not corresponding with CA SR 2006. Numbers of sulfite-reducing clostridia, coagulase positive staphylococci did not exceed $10 \mathrm{cfu}^{-1} \mathrm{~g}^{-1}$ while the isolation range of yeasts and microscopic and filamentous fungi was from $<10$ to $5.0 \times 10^{2} \mathrm{cfu}^{-\mathrm{g}^{-1}}$ and $1.8 \times 10^{2}$ cfu. $\mathrm{g}^{-1}$, respectively. These microbiological quality indicators of the samples were with the requirements of Codex Alimentarius of SR (CA SR, 2006).

Our results indicate the microbiological quality of the tested samples was better than in previously conducted studies. In 30 samples of kebab in Agbodaze et al., 2005 research, the mean total plate count (TPC) at Osu was 5.02, Accra Central 4.08 and those from Nima $4.80 \log _{10}$ CFU/g. The samples from Accra Central shared the highest mean coliform count - 5.12, while the samples from Osu and Nima - 4.41 and $3.70 \log _{10}$ cfu.g $^{-1}$, respectively. Accra Central samples again recorded the highest fecal coliforms $\left(4.4 \log _{10} \mathrm{cfu}^{-1} \mathrm{~g}^{-1}\right)$ as compared to 3.98 and $3.80 \log 10$ cfu. $^{-1}$ for samples bought from Osu and Nima, respectively. Kebab samples from sites were contaminated with $E$. coli, other Gram-negative bacteria and Staphylococcus species, whose virulence factors are yet to be determined. In study of Ziino et al. (2013) the microbiological quality of kebabs retailed in Palermo and Messina was evaluated and 20 raw and 22 cooked kebabs were analysed to determine the aerobic mesophilic bacteria (AMB), Enterobacteriaceae, Escherichia coli, sulphite reducing anaerobes, coagulase positive staphylococci, micrococci, Bacillus cereus and the presence of Salmonella spp. and Listeria monocytogenes. In raw kebabs, AMB ranged from 4.00 to $7.34 \mathrm{log}$ cfu.g ${ }^{-1}$ and Enterobacteriaceae from 1.00 to $7.59 \log \mathrm{cfu}^{-1}{ }^{-1}$ Escherichia coli and sulphite reducing anaerobe counts were from $<1.00$ to 6.18 and $4 \log$ cfu. $\mathrm{g}^{-1}$, respectively. Coagulase positive staphylococci ranged from $<1.00$ to $3.48 \mathrm{log}$ cfu. $\mathrm{g}^{-1}$ and micrococci from $<1.00$ to $6.00 \mathrm{log}$ cfu. $\mathrm{g}^{-1}$. Listeria spp. was found in three raw kebab samples. In cooked kebabs, the AMB values ranged from 1.78 to $6.30 \mathrm{log} \mathrm{cfu}^{\mathrm{g}} \mathrm{g}^{-1}$, Enterobacteriaceae from 1.00 to $4.00 \mathrm{log}$ cfu. $\mathrm{g}^{-1}$ and micrococci from $<1.00$ to $5.30 \mathrm{log} \mathrm{cfu}^{\mathrm{g}} \mathrm{g}^{-1}$. Three samples were positive for Escherichia coli (from 1 to $1.30 \log \mathrm{cfu}_{\mathrm{g}} \mathrm{g}^{-1}$ ) and one for sulphite reducing anaerobes $\left(2.00 \mathrm{log}\right.$ cfu. $\left.\mathrm{g}^{-1}\right)$. Coagulase positive staphylococci were found in two samples with loads of 2.30 and $2.78 \mathrm{cfu}^{-\mathrm{g}^{-1}}$, respectively.

Kebab is product, which is frequently to find to be contaminated and also the results of our study in $40 \%$ was non satisfactory and the microbiological quality of kebab should be monitored.

In gyros samples the numbers of coliform bacteria was from less to 10 to $1.5 \times 10^{3}$ cfu. $\mathrm{g}^{-1}$, but the numbers of yeasts was from less than 10 to $1.4 \times 10^{2} \mathrm{cfu}^{-\mathrm{g}^{-1}}$ and of fungi from less than 10 to $1.2 \times 10^{2} \mathrm{cfu}^{-1} \mathrm{~g}^{-1}$. Counts of yeasts and coagulase positive staphylococci did not exceed $10 \mathrm{cfu}^{-1} \mathrm{~g}^{-1}$ (Table 3).

Table 3 Microbiological quality of gyros samples $(n=10)$

\begin{tabular}{lcc}
\hline Microorganisms & Results & $\begin{array}{c}\text { No. of unsatisfactory } \\
\text { samples } / \text { No. of samples } \\
(\%)\end{array}$ \\
\hline $\begin{array}{l}\text { Coliform bacteria } \\
\begin{array}{l}\text { Sulfite-reducing } \\
\text { clostridia }\end{array}\end{array}$ & $<10-1.5 \times 10^{3} \mathrm{cfu} . \mathrm{g}^{-1}$ & $2 / 10(20)$ \\
$\begin{array}{l}\text { Yeasts } \\
\text { Microscopic } \\
\text { filamentous fungi }\end{array}$ & $<10 \mathrm{cfu} \cdot \mathrm{g}^{-1}$ & $0 / 0(0)$ \\
$\begin{array}{l}\text { Coagulase } \\
\text { positive } \\
\text { staphylococci }\end{array}$ & $<10-1.4 \times 10^{2} \mathrm{cfu} . \mathrm{g}^{-1}$ & $1 / 10(10)$ \\
\hline
\end{tabular}

In gyros samples, we found that two samples (2/10/20) did not meet the acceptable value for coliforms bacteria and one samples of gyros (1/10/10) did not corresponding of acceptable value of yeast.

Number of unsatisfactory samples in case of gyros was higher than in case of kebab. The gyros usually is manufactured from the poultry meat and the poultry meat was found to be contaminated with high numbers of bacteria. Bacterial counts (aerobes, Salmonella spp., E. coli, C. jejuni, and C. coli) are higher on the breast area of broiler carcasses than on the thigh and drum areas. In addition, some microorganisms particularly Salmonella spp. attaches to the poultry skin and is difficult to remove (Kotula and Davis, 1999). A great risk may be occurred by these pathogens, when chicken skin is added to chicken doner kebabs. Thus, some manufactures recommend that the skin using in doner kebabs can be heated to increase chemical and microbiological quality of chicken doner kebabs. Doner kebab as well as gyros are a traditional products. If it is produced properly, there have no any microbiologically serious risk. In general, the microbiological quality of gyros could be improved through implementation of the hazard analysis critical control point (HACCP) concept for the chicken doner kebab and gyros because the incompliance in case of gyros we identified more frequently than in case of kebab. 
Table 4 Microbiological quality of hamburger samples $(n=54)$

\begin{tabular}{|c|c|c|}
\hline Microorganisms & Results & $\begin{array}{c}\text { No. of unsatisfactory } \\
\text { samples /No. of samples } \\
(\%)\end{array}$ \\
\hline Coliform bacteria & $<10-2.2 \times 10^{3}$ cfu. $^{-1}$ & $10 / 54(19)$ \\
\hline $\begin{array}{l}\text { Sulfite-reducing } \\
\text { clostridia }\end{array}$ & $<10$ cfu.g $\mathrm{g}^{-1}$ & $0 / 0(0)$ \\
\hline Yeasts & $<10-8.2 \times 10^{2} \mathrm{cfu}^{-1} \mathrm{~g}^{-1}$ & $1 / 54(2)$ \\
\hline $\begin{array}{l}\text { Microscopic } \\
\text { filamentous fungi }\end{array}$ & $<10-2.0 \times 10^{2}$ cfu. ${ }^{-1}$ & $0 / 0(0)$ \\
\hline $\begin{array}{l}\text { Coagulase } \\
\text { positive } \\
\text { staphylococci }\end{array}$ & $<10$ cfu. $\mathrm{g}^{-1}$ & $0 / 0(0)$ \\
\hline
\end{tabular}

In Min et al. (2013) study an amount of 20 RTE hamburgers sold in Canterbury region were tested for Listeria monocytogenes, Staphylococcus aureus, coliforms and Escherichia coli. Among samples were 13 chicken and 7 beef burgers, respectively, which were purchased from five fish and chip shops located in the different areas over period of 4 weeks. Overall, $16(80 \%)$ and $4(20 \%)$ samples were found to be of satisfactory and marginal microbiological quality, respectively. None of the samples tested was in the category of unsatisfactory or potentially hazardous levels of microbial counts. Among the 4 burger samples with marginal microbiological quality two chicken burgers were contaminated with coliforms $\left(1.50 \times 10^{2}\right.$ and $\left.2.25 \times 10^{2} \mathrm{cfu}^{-1}\right)$, but one chicken and one beef burgers with $S$. aureus $\left(1.05 \times 10^{2}\right.$ and $\left.2.30 \times 10^{2} \mathrm{cfu}^{-1}\right)$. E. coli and $L$. monocytogenes were not detected in any samples. Results indicate that the microbiological quality of burgers sold in different shops in Canterbury was satisfactory

In study of Dinucci Bezerra et al., 2010 an amount of 105 hamburgers were evaluated for facultative aerobic and/or anaerobic mesophilic bacteria, coliform counts, Staphylococcus, Bacillus cereus, sulfite-reducing clostridia and Salmonella spp. The hamburgers were unsuitable for human consumption in $31.4 \%$ of cases because the positive samples for coliforms and Staphylococcus were contaminated at unacceptably high levels set by Brazilian standards.

In cheeseburgers, sulfite-reducing clostridia and coagulase positive staphylococci were less than $<10 \mathrm{cfu} . \mathrm{g}^{-1}$ but the highest counts were detected for coliforms which were isolated from samples in up to $1.5 \times 10^{3} \mathrm{cfu}^{-\mathrm{g}^{-1}}$ high counts (Table 5)

Table 5 Microbiological quality of cheeseburger samples ( $n=5$ )

\begin{tabular}{lcc}
\hline Microorganisms & Results & $\begin{array}{c}\text { No. of unsatisfactory } \\
\text { samples } / \text { No. of samples } \\
(\%)\end{array}$ \\
\hline $\begin{array}{l}\text { Coliform bacteria } \\
\text { Sulfite-reducing } \\
\text { clostridia }\end{array}$ & $<10-1.5 \times 10^{3} \mathrm{cfu}^{-1}$ & $2 / 5(40)$ \\
$\begin{array}{l}\text { Yeasts } \\
\text { Microscopic }\end{array}$ & $<10 \mathrm{cfu} \cdot \mathrm{g}^{-1}$ & $0 / 0(0)$ \\
filamentous fungi & $<10-5.0 \times 10^{2} \mathrm{cfu}^{-1}$ & $0 / 0(0)$ \\
$\begin{array}{l}\text { Coagulase } \\
\text { positive }\end{array}$ & $<10 \mathrm{cfu} . \mathrm{g}^{-1}$ & $0 / 0(0)$ \\
staphylococci & & $0 / 0(0)$ \\
\hline
\end{tabular}

Evaluating the microbiological quality of cheeseburgers, two samples $(40 \%)$ were not accordance with the requirements of CA SR 2006. Cheesburgers and other sandwiches were found to be contaminated in previous studies and studies on the microbiological quality of sandwiches sold on the streets of São Paulo and Rio Grande do Sul showed high levels of contamination by fecal Coliforms (Lopes, 2005). These results probably reflect the inappropriate conditions during the preparation of food -dirtiness of the water used for hand washing by the sandwich makers, insufficient hand washing, insufficiently-heated food, and unsuitable conditions of ingredients storage. Therefore, the likelihood of contamination by fecal coliforms in the sandwiches sold on Brazilian roadsides is similar to that which occurs in other countries in Latin America (Garinet al., 2002). Results of the present study show that the contamination of cheeseburger samples could be an actual problem for food retailed in Slovakia.

In hot-dogs, the lowest isolation rates were obtained for coliform sulfite-reducing clostridia and microscopic filamentous fungi - less than $10 \mathrm{cfu}^{-1} \mathrm{~g}^{-1}$ and less than 10 to $2.4 \times 10^{2} \mathrm{cfu}^{-1} \mathrm{~g}^{-1}$, respectively. The highest counts were obtained for coliform bacteria, yeasts and coagulase positive staphylococci (Table 6).
Table 6 Microbiological quality of hot-dog samples ( $\mathrm{n}=31)$

\begin{tabular}{|c|c|c|}
\hline Microorganisms & Results & $\begin{array}{l}\text { No. of unsatisfactory } \\
\text { samples /No. of samples } \\
(\%)\end{array}$ \\
\hline Coliform bacteria & $<10-1.4 \times 10^{3}$ cfu. $\mathrm{g}^{-1}$ & $3 / 31(10)$ \\
\hline $\begin{array}{l}\text { Sulfite-reducing } \\
\text { clostridia }\end{array}$ & $<10$ cfu. $\mathrm{g}^{-1}$ & 0/0 (0) \\
\hline Yeasts & $<10-2.1 \times 10^{3}$ cfu. $\mathrm{g}^{-1}$ & 1/31 (3) \\
\hline $\begin{array}{l}\text { Microscopic } \\
\text { filamentous fungi }\end{array}$ & $<10-2.4 \times 10^{2}$ cfu.g ${ }^{-1}$ & $0 / 0(0)$ \\
\hline $\begin{array}{l}\text { Coagulase } \\
\text { positive } \\
\text { staphylococci }\end{array}$ & $<10-1.4 \times 10^{2}$ cfu. $\mathrm{g}^{-1}$ & 1/31 (3) \\
\hline
\end{tabular}

Among the hot-dog samples three (3/31/ 10) shared the counts of coliform bacteria which were not in accordance with the limit set by CA SR 2006 and the testing results ranged from less than 10 to $1.4 \times 10^{3} \mathrm{cfu}^{\mathrm{g}} \mathrm{g}^{-1}$. Yeasts counts ranged from less tan 10 to $2.1 .10^{3}$ cfu. $^{-1}$ and one sample (1/31/3)had unsatisfactory results. Coagulase positive staphylococci values were from less than 10 to $1.4 \times 10^{2}$ cfu. $\mathrm{g}^{-1}$ and one sample had unsatisfactory results.

Hot-dogs are frequently are found to be contaminated with coliforms and staphylococci and this corresponds to our results (Kothe et al., 2016). In Kothe et al., 2016) study, $75 \%$ of the hot-dogs were contaminated with total coliforms, $30 \%$ of them presented fecal coliforms while $25 \%$ coagulase-positive staphylococci levels above the maximum limit permitted by Brazilian regulations. Reason for this could ne not adequate hygienic and sanitary conditions of hot-dog vendors in Southern Brazil and this results were based on questionnaire completed for evaluation of sanitary conditions of vendors. Unconformities related to storage of defrosted sausages at environmental temperature or inadequate cooling, absence of thermometer in vendors, usage of non-potable water were described. The lack of cross contamination preventive measures, lack of time and temperature controls and the use of ingredients with unknown origins were also the important factors which could influence the microbiological safety of hot-dogs in Southern Brazil (Kothe et al., 2016).

In roasts, counts of sulfite-reducing clostridia and coagulase positive staphylococci were less than $10 \mathrm{cfu}^{-1} \mathrm{~g}^{-1}$, but coliforms, yeasts and microscopic filamentous fungi ranged from less than 10 to $2.1 \times 10^{2} \mathrm{cfu}^{-1}{ }^{-1}$, less than 10 to 3.6.x $10^{3}$ cfu.g $\mathrm{g}^{-1}$ and less than 10 to $3.2 \times 10^{2} \mathrm{cfu}^{-\mathrm{g}^{-1}}$ respectively (Table 7 ).

Table 7 Microbiological quality of in roasts $(\mathrm{n}=14)$

\begin{tabular}{|c|c|c|}
\hline Microorganisms & Results & $\begin{array}{c}\text { No. of unsatisfactory } \\
\text { samples /No. of samples } \\
(\%)\end{array}$ \\
\hline Coliform bacteria & $<10-2.1 \times 10^{2}$ cfu. $\mathrm{g}^{-1}$ & $1 / 14(7)$ \\
\hline $\begin{array}{l}\text { Sulfite-reducing } \\
\text { clostridia }\end{array}$ & $<10$ cfu.g ${ }^{-1}$ & $0 / 0(0)$ \\
\hline Yeasts & $<10-3.6 \times 10^{3}$ cfu. $\mathrm{g}^{-1}$ & $1 / 14(7)$ \\
\hline $\begin{array}{l}\text { Microscopic } \\
\text { filamentous fungi }\end{array}$ & $<10-3.2 \times 10^{2}$ cfu. $\mathrm{g}^{-1}$ & $1 / 14(7)$ \\
\hline $\begin{array}{l}\text { Coagulase } \\
\text { positive } \\
\text { staphylococci }\end{array}$ & $<10$ cfu.g $\mathrm{g}^{-1}$ & $0 / 0(0)$ \\
\hline
\end{tabular}

Regarding conformity with microbiological quality criteria, in roasts in one sample 1/ 14 (7) the counts of coliforms did not meet the critera were set. The counts of yearsts and of microscopic filamentous fungi were unsatisfactory in $1 / 14$ (7) and 1/14 (7) of samples, respectively. The safety of foods is affected by several common factors including the quality of the raw materials, food handling and storage practices. In RTE street vendors the hygiene is mostly affected, that could led to contamination of foods. In most cases, running water is not continuously supplied for hand and dishwashing, cooking or drinking, leading the street vendors to store water under vulnerable conditions subject to contamination. Street foods are exposed to aggravating environmental conditions, such as the presence of insects, rodents, other animals and air pollution studies (Lucca and Torres, 2002; Sobel et al., 1998). Furthermore, most food vendors ignore good food handling practices, exposing foods to dangerous conditions such as cross-contamination, unsafe storage and poor time-temperature conditions (Ekanem, 1998).

The presence of fecal coliforms $(30 \%)$ in the samples in the previous study indicates a high risk that other pathogenic organisms have also contaminated the food. E. coli was present in $22.5 \%$ of the samples, probably from raw vegetables and due to the lack of good hygienic practices. and $70 \%$ of tuna and $40 \%$ of chicken sandwiches were unsuitable according to the sanitary standards for fecal coliforms in study completed in the northen region of Brazil (Damsceno and Cardonha, 1999).

In general, the microbiological criteria set for RTE foods in Slovak Republic were violated in 36/ 144 (25). Mostly, unconformity with the microbiological criteria were observed for kebabs and cheeseburgers - $40 \%$ for each, respectively. The lowest amount of unsatisfactory samples were observed among 
the hot-dogs were tested $-9.67 \%$. Distribution of unsatisfactory samples of RTE food products produced in Slovak Republic is shown in Figure 1.

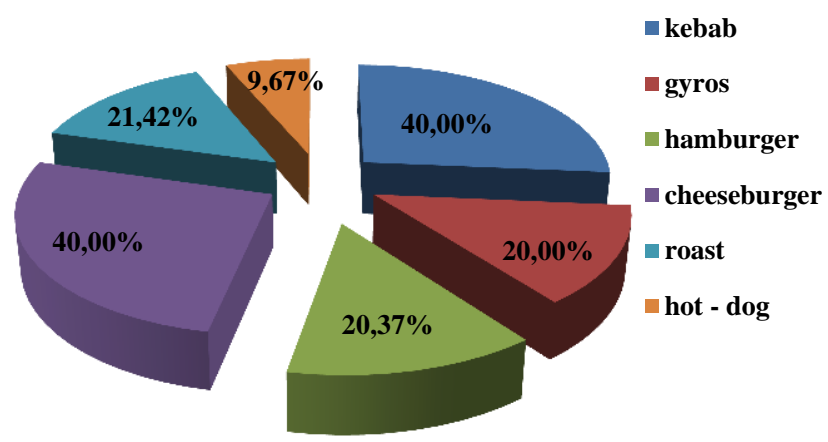

Figure 1 Distribution of unsatisfactory samples $(n=36)$ according to the microbiological criteria set by SR CA, 2006

The results of the present study show that unconformity with the microbiological criteria was faced in $25 \%$ of all samples tested, therefore RTE foods produced in Slovakia should considered to pose a possible risk to consumers. The efficien use of HACCP can improved the microbiological safety and quality of these products (Vazgecer et al., 2004).

\section{CONCLUSION}

Finally, we hope that the systematic microbiological testing of the RTE foods as conducted at the present study could help to assess a risk which poses each RTE product and to define better the control measures needed in order to prevent foodborne infections related to the consumption of RTE foods. This research shows that eating of RTE foods might pose public health concerns even though as there have not been any report of outbreaks related to consumption of RTE foods in Slovakia. However, to ensure the safety and health of their customers, fast-food restaurants should inculcate good hygienic practices and habits in their staff and food processing. The critical control points to preventing food borne illness such as preventing cross - contamination from the raw products to RTE foods, using adequate time and temperatures for cooking, avoiding recontamination after cooking, by surfaces previously contaminated with the raw meat, and properly chilling and storing meat after mincing should be emphasized. Food handlers should also be trained on hygienic food handling practices and safety.

Acknowledgments: This work was supported by grant VEGA 1/0611/14.

\section{REFERENCES}

Agbodaze, D., Nmai, P., Robertson, F., Yeboah-Manu, D., Owusu-Darko, K. \& Addo, K. (2005). Microbiological quality of "khebab" consumed in the accra metropolis. Ghana Medical Journal, 39(2), 46-9. http://dx.doi.org/10.4314/gmj.v39i2.35981

Almualla, N. A., Laleye, L. C., Abushelaibi, A. A., Al-Qassemi, R. A., Wasesa, A. A., \& Baboucarr, J. (2010). Aspects of the microbiological quality and safety of ready-to-eat foods in Sharjah supermarkets in the United Arab Emirates. Journal of Food Protection, 73(7), 1328-1331.

Castro-Rosas, J., Cerna-Cortés, J. F., Méndez-Reyes, E., Lopez-Hernandez, D. GómezAldapa, C. A., \& Estrada-Garcia, T. (2012). Presence of faecal coliforms, Escherichia coli and diarrheagenic E. coli pathotypes in ready-to-eat salads, from an area where crops are irrigated with untreated sewage water. International Journal of Food Microbiology, 156(2), 176-180. http://dx.doi.org/10.1016/j.ijfoodmicro.2012.03.025

Christison, C. A., Lindsay, D., \& von Holy, A. (2008). Microbiological survey of readyto-eat foods and associated preparation surfaces in retail delicatessens, Johannesburg, South Africa. Food Control, 19(7), 727-733. http://dx.doi.org/10.1016/j.foodcont.2007.07.004

Chapman, B., Eversley, T., Fillion, K., MacLaurin, T. \& Powell, D. (2010) Assessment of food safety practices of food service food handlers (risk assessment data): testing a communication intervention (evaluation of tools) Journal of Food Protection, 73(6), 1101-1107.

Codex Alimentorius SR 2006. Potravinový kódex SR 2006: Výnos MP SR a MZ SR zo 6. februára 2006 č. 06267/2006-SL, ktorým sa vydáva hlava PK SR upravujúca mikrobiologické požiadavky na potraviny a na obaly na ich balenie. p. 1-62. Available at: http://www.svps.sk/legislativa/legislativa_kodex.asp.

Damsceno, K. S. F. S. C., \& Cardonha, A. M. S. (1999). Perfil microbiologico de "sandu 1ches naturais" comercializados em Natal nas lanchonetes da Universidade Federal do Rio Grande do Norte. Revista Higiene Alimentar, $13(65), 47-50$.
Dinucci Bezerra, A.C., Baptista dos Reis, R., Markowicz Bastos, D.H. (2010) Microbiological quality of hamburgers sold in the streets of Cuiabá - MT, Brazil and vendor hygiene-awareness. Ciência e Tecnologia de Alimentos, 30(2), 520524. http://dx.doi.org/10.1590/S0101-20612010000200035

Dinucci Bezerra, A.C., Baptista dos Reis, R., Markowicz Bastos, D.H. (2010) Microbiological quality of hamburgers sold in the streets of Cuiabá - MT, Brazil and vendor hygiene-awareness. Ciência e Tecnologia de Alimentos, 30(2), 520524. http://dx.doi.org/10.1590/S0101-20612010000200035

Ekanem, E. O. (1998). The street food trade in Africa: Safety and socioenvironmental issues. Food Control, 9(14), 211-215. http://dx.doi.org/10.1016/s0956-7135(97)00085-6

European Food Safety Authority, European Centre for Disease Prevention and Control. (2011). The European Union summary report on trends and sources of zoonoses, zoonotic agents and food-borne outbreaks in 2009. EFSA Journal, 9(3), 2090 [378 pp.]. Available online. www.efsa.europa.eu/efsajournal.

Evans, M. R., Sarvotham, T., Thomas, D. R., \& Howard, A. J. (2006). Domestic and travel-related foodborne gastrointestinal illness in a population health survey. Epidemiology and Infection, 134(4), 686-693. http://dx.doi.org/10.1017/s0950268805005790

Fang, T. J., Wei, Q. K., Liao, C. W., Hung, M. J., \& Wang, T. H. (2003) Microbiological quality of $18 \mathrm{C}$ ready-to-eat food products sold in Taiwan International Journal of Food Microbiology, 80(3), 241-250. http://dx.doi.org/10.1016/s0168-1605(02)00172-1

FEHD (Food and Environmental Hygiene Department). (2007). Microbiological guidelines for ready-to-eat food.

Garayoa, R., Vitas, A. I., Díez-Leturia, M. \& García-Jalón, I. (2011). Food safety and the contract catering companies: food handlers, facilities and HACCP $\begin{array}{llll}\text { evaluation. Food } & \text { Control, } & 22, & \text { 2006-2012 }\end{array}$ http://dx.doi.org/10.1016/j.foodcont.2011.05.021

Garin, B., Aïdara, A., Spiegel, A., Arrive, P., Bastaraud, A., Cartel, J.L., Aissa, R.B., Duval, P., Gay, M., Gherardi, C., Gouali, M., Karou, T.G., Kruy, S.L., Soares, J.L., Mouffok, F., Ravaonindrina, N., Rasolofonirina, N., Pham, M.T., Wouafo, M., Catteau, M., Mathiot, C., Mauclere, P., \& Rocourt, J. Multicenter study of street foods in 13 towns on four continents by the food and environmental hygiene study group of the international network of Pasteur and Associated Institutes. Journal of Food Protection, 65(1), 146-152.

Gillespie, I., Little, C. \& Mitchell, R. (2000). Microbiological examination of cold ready-to-eat sliced meats from catering establishments in the United Kingdom. Journal of Applied Microbiology, 88, 467-474. http://dx.doi.org/10.1046/j.1365-2672.2000.00981.x

Microbiological quality of selected street foods from a restricted area of S ao Paulo city, Brazil Agnes Hanashiro, Marisa Morita, Glavur R. Matte, Maria H. Matte *, Elizabeth A.F.S. Torres. Food Control 16 (2005) 439-444

Käferstein, F. K., Motarjemi, Y., \& Bettcher, D. W. (1997). Foodborne disease control: a transnational challenge. Emerging Infectious Diseases, 3(4), 503-510. http://dx.doi.org/10.3201/eid0304.970414

Kothe, C.I., Schild, C.H., Tondo, T.C., \& da Silva Malheiros, P. (2016) Microbiological contamination and evaluation of sanitary conditions of hot dog street vendors in Southern Brazil. Food Control, 62, 346-350. http://dx.doi.org/10.1016/i.foodcont.2015.11.005

Kotula, K. L., \& Davis, M. E. (1999). Broiler skin sampling for optimum recovery of Salmonella spp. Journal of Food Protection, 62(3), 284-286.

Legnani, P., Leoni, E., Berveglieri, M., Mirolo, G., \& Alvaro, N. (2004). Hygienic control of mass catering establishments, microbiological monitoring of food and equipment. Food Control, 15, 205-211. http://dx.doi.org/10.1016/s0956-7135(03)00048-3

Lopes, G.V. (2005). Alimentos de rua: quão perigosos eles são? Diário Popular 2005. Disponível em: 〈http://www.diariopopular.com.br/22 11 05/artigo.html〉. Lucca, A., \& Torres, E. A. F. S. (2002). Condicoes de higiene de "cachorroquente" comercializado em vias publicas. Revista de Sau de Publica, 36(3), 350-352. http://dx.doi.org/10.1590/s0034-89102002000300015

Martinez-Tomé, M., Vera, A. M., \& Murcia, M. (2000). Improving the control of food production in catering establishments with particular reference to the safety of salads. Food Control, 11, 437-445. http://dx.doi.org/10.1016/s09567135(00)00006-2

Martins, E. A., \& Germano, P. M. L. (2008). Microbiological indicators for the assessment of performance in the hazard analysis and critical control points (HACCP) system in meat lasagna production. Food Control, 19, 764-771. http://dx.doi.org/10.1016/j.foodcont.2007.08.001

Marzano, M. A., \& Balzaretti, C. M. (2011). Cook-serve method in mass catering establishments: is it still appropriate to ensure a high level of microbiological quality and safety? Food Control, 22, 1844-1850. http://dx.doi.org/10.1016/j.foodcont.2011.04.024

Mataragas, M., Skandamis, P.N., \& Drosinos, E.H., 2008. Risk profiles of pork and poultry meat and risk ratings of various pathogen/product combinations. International Journal of Food Microbiology, 126(1-2), 1-12. http://dx.doi.org/10.1016/j.ijfoodmicro.2008.05.014

Min, M., Dawson, C.O., \& Hussain, M.A. (2013). Microbiological Risk Assessment of Hamburgers Sold in Canterbury New Zealand. Internet Journal of Food Safety, 13, 99-102 
Ravel, A., Nesbitt, A., Marshall, B., Sittler, N., \& Pollari, F. (2011). Description and burden of travel-related cases caused by enteropathogens reported in a Canadian community. Journal of Travel Medicine, 18(1), 8-19. http://dx.doi.org/10.1111/j.1708-8305.2010.00471.x

Rodríguez, M., Valero, A., Carrasco, E., Pérez-Rodríguez, F., Posada, G. D., \& Zurera, G. (2011a). Hygienic conditions and microbiological status of chilled ready-to-eat products served in Southern Spanish hospitals. Food Control, 22, 874-882. http://dx.doi.org/10.1016/j.foodcont.2010.11.015

Rodríguez, M., Valero, A., Posada-Izquierdo, G. D., Carrasco, E., \& Zurera, G. (2011b). Evaluation of food handler practices and microbiological status of ready-to-eat foods in long-term care facilities in Andalusia Region of Spain Journal of Food Protection, 74(9), 1504-1512.

Santana, N. G., Almeida, R. C. C., Ferreira, J. S., \& Almeida, P. F. (2009) Microbiological quality and safety of meals served to children and adoption of good manufacturing practices in public school catering in Brazil. Food Control, 20, 255-261. http://dx.doi.org/10.1016/j.foodcont.2008.05.004

Seow, J., Ágoston, R., Phua, L., \& Yuk, H. G. (2012). Microbiological quality of fresh vegetables and fruits sold in Singapore. Food Control, 25(1), 39-44. http://dx.doi.org/10.1016/j.foodcont.2011.10.017

Sobel, J., Mahon, B., Mendoza, C. E., Passaro, D., Cano, F., Baier, K., Racioppi, F., Hutwagner, L., \& Mintz, E. (1998). Reduction of fecal contamination of street-vended beverages in Guatemala by a simple system for water purification and storage, handwashing, and beverage storage. American Journal of Tropical Medicine Hygiene, 59(3), 380-387.

STN EN ISO 4932: 2006. Microbiology of food and animal feeding stuffs. Horizontal method for the enumeration of coliforms. Colony-count technique.

STN EN ISO 13401: 2001. Microbiology of food and animal feeding stuffs. Horizontal method for the enumeration of Clostridium perfringens. Colony-count technique.

STN EN ISO 6888-1: 2001. Microbiology of food and animal feeding stuffs. Horizontal method for the enumeration of coagulase-positive staphylococci (Staphylococcus aureus and other species). Part 1: Technique using Baird-Parker agar medium.

STN EN ISO 21527-2: 2010. Microbiology of food and animal feeding stuffs. Horizontal method for the enumeration of yeast and moulds. Part 1, Colonycount technique in products with water activity greater than $0,95=$

Tessi, M. A., Arìngoli, E. E., Pirovani, M. E., Vincenzini, A. Z., Sabbag, N. G.,

Costa, S. C., Garcia, C.C., Zannier, M.S., Silva, E.R., \& Moguilevsky, M.A. (2002). Microbiological quality and safety of ready-to-eat cooked foods from a centralized school kitchen in Argentina. Journal of Food Protection, 65(4), 636642

United Nation World Tourism Organization. (2011). UNWTO annual report 2010 a year of recovery. Madrid: Spain, Available from https://s3-eu-west-1. amazonaws.com/storageapi/sites/all/files/pdf/final_annual_report_pdf.pdf.

USFDA (United States Food and Drug Administration). (2009). Food code 2009. Vazgecer, B., Ulu, H. \& Oztan, A 2009. Microbiological and chemical qualities of chicken doner $€$ kebab retailed on the Turkish restaurants. Food Control, 15, 261-264. http://dx.doi.org/10.1016/s0956-7135(03)00065-3

Veiros, M. B., Proença, R. P. C., Santos, M. C. T., Kent-Smith, L., \& Rocha, A (2009). Food safety practices in a Portuguese canteen. Food Control, 20, 936941. http://dx.doi.org/10.1016/j.foodcont.2009.02.002

Verbeke, W., Pérez-Cueto, F.J.A., Barcellos, M.D., Krystallis, A., \& Grunert, K.G. (2010). European citizen and consumer attitudes and preferences regarding beef and pork. Meat Science, 84(2), 284-292. http://dx.doi.org/10.1016/j.meatsci.2009.05.001

World Health Organization. (2007). Food safety and foodborne illness e Fact sheet no. 237. Available from http://www.who.int/mediacentre/ factsheets/ fs237/en/.

Yoon, Y., Kim, S. R., Kang, D. H., Shim, W. B., Seo, E., \& Chung, D. H. (2008)

Microbial assessment in the school foodservices and recommendations for food safety improvement. Journal of Food Science, 73(6), M304-M313. http://dx.doi.org/10.1111/j.1750-3841.2008.00828.x

Ziino, G., Gurrera, G., \& Beninati, C. Microbiological quality of kebabs sold in Palermo and Messina. Italian journal of food safety, 2, 277-80. http://dx.doi.org/10.4081/ijfs.2013.e23 